\title{
Bio-Diesel From used Cooking Oil
}

\author{
Aswan Jyothibabu \\ Student: Department of Mechanical Engineering \\ Rajadhani Institute of Engineering and Technology (RIET) \\ Thiruvananthapuram, India
}

\section{Aravind A}

Student: Department of Mechanical Engineering Rajadhani Institute of Engineering and Technology (RIET)

Thiruvananthapuram, India

\section{Amal Das}

Student: Department of Mechanical Engineering Rajadhani Institute of Engineering and Technology (RIET) Thiruvananthapuram, India

\begin{abstract}
Biodiesel is an efficient substitute for diesel due to its unique properties like cutback in greenhouse gas emissions, nonsulfur emissions, non-particulate matter pollutants and insignificant toxicity and biodegradability. This not only helps to reduce the pollution level; it is also cheaper compared to other modes of fuel. When UCO is used as feedstock this again reduces the production cost. In this project, we have used UCO as feedstock and analysed the performance rate(mileage).
\end{abstract}

\section{Keywords_-Bio Diesel; Used Cooking Oil;}

\section{INTRODUCTION}

In the last decades, energy consumption has increased significantly due to the change in lifestyles and growth of population. The energy consumption of the planet is everincreasing; this has caused the fuel resources to dwindle. it's been anticipated that fuel is exhausted within the near future. fuel is that the key component within the field of agriculture, transport, domestic, commercial and industry for the assembly of power/mechanical energy, transport sector worldwide has considerably increased reaching $61.5 \%$. fuel combustion has several public health risks and environmental problems which touch universal and potentially irreversible consequences on global warming, rate of emission of gas, carbon dioxide and other gases are high.

Biodiesel is an alternate fuel derived from vegetable oils or animal fats. Triglycerides or glycerol is that the fundamental component of edible fat and fat. Biodiesel and traditional diesel blended in an exceeding ratio is utilized in the functioning of compression ignition engine and doesn't require remodeling of the prevailing engine. Waste vegetable oil has always been an environmental problem in food factories so, Converting the UCO into biodiesel will reduce this problem. Biodiesel from used oil (UCO) can reduce the assembly cost since $70-95 \%$ of the general cost of biodiesel production is of feedstock cost.

\section{METHODOLOGY}

This process starts with the filtration of Used Cooking Oil(UCO) by transesterification process, using an alcohol solution. The mixture is then rested for some time to separate the biodiesel from the mixture resulted after this process.

\author{
Abhilash Kumar Nair \\ Student: Department of Mechanical Engineering \\ Rajadhani Institute of Engineering and Technology (RIET) \\ Thiruvananthapuram, India \\ K. Krishnakumar \\ Assistant Professor: Department of Mechanical Engineering \\ Rajadhani Institute of Engineering and Technology (RIET) \\ Thiruvananthapuram, India \\ Dr. M D Sreekumar \\ Head of Department: Department of Mechanical Engineering \\ Rajadhani Institute of Engineering and Technology (RIET) \\ Thiruvananthapuram, India
}

\section{A. Selection Of Used Cooking Oil}

The production of waste cooking oil taken for conducting this experiment mainly comes from the frying of vegetables. They were collected from local sources. The used oil sample will be bought in big batches for easy convenience to transport We took both used sunflower oil and coconut oil separately. The collected used oil then labelled for easy detection on usage.

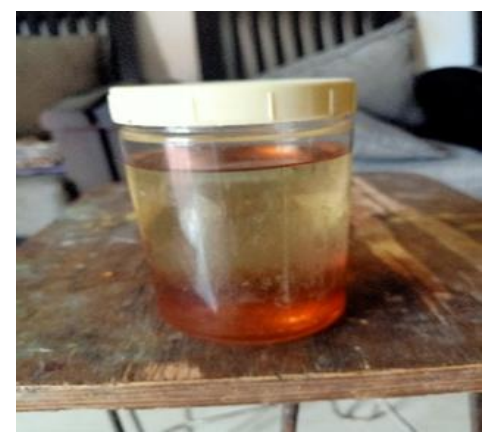

Figure 1 (Used Cooking Oil (UCO))

\section{B. Filtration of UCO}

The collected used oil samples needed to be filtered as it contained various impurities from the frying processes, mostly the burnt vegetable parts and burnt carbon compounds. For converting UCO to biodiesel we need to remove these impurities from our oil samples otherwise the resulting product losses it's quality and will be performing less as expected. Thus we filter the oil sample by using a filter paper sheet shaped like a funnel. The oil sample will be allowed to pass through this filter paper funnel slowly so that the sample will be completely filtered and can be used for the production of biodiesel.

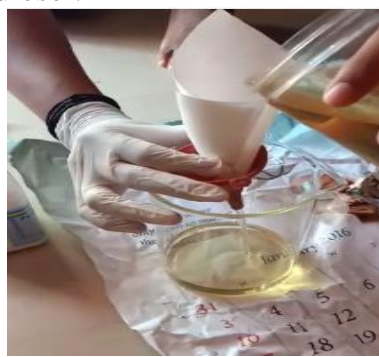

Figure 2 (Filtration Process) 


\section{Transesterification}

Transesterification process is conducted to transform UCO into biodiesel. Potassium hydroxide was used as a catalyst in this process. The amount of catalyst in the solution taken directly effect the conversion of esters during the transesterification process. Before the transesterification process Potassium hydroxide was first mixed with methanol together in a beaker before adding to the used cooking oil. After adding the methanol/potassium hydroxide and waste cooking oil together, take a stirrer and stir for some time until the solution changes the colour darker and gloomy. Then the solution will be heated in the water bath taken at a constant temperature for half an hour.

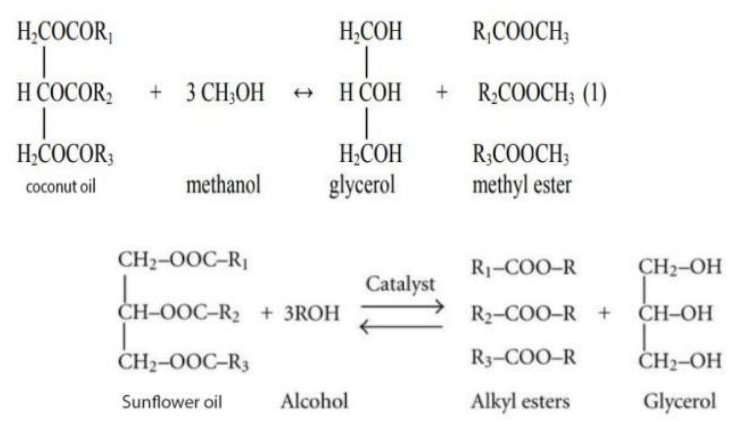

Figure 3 (Chemical Equation for the processes with Used coconut oil and Used sunflower oil)

\section{Separation}

Separation process was used to separate the top (methyl ester) and bottom (glycerol) layers of the biodiesel samples. Two layers could be seen after the transesterification of biodiesel samples. The top layer was mainly composed of free fatty acid methyl esters which the awaited result from our experiment, i.e. the component to mix with the diesel to produce biodiesel. The bottom part is mainly glycerol, soaps, impurities, which is the byproduct from the process, hence generally rejected but we can create revenue by cleaning this mixture to make soap.

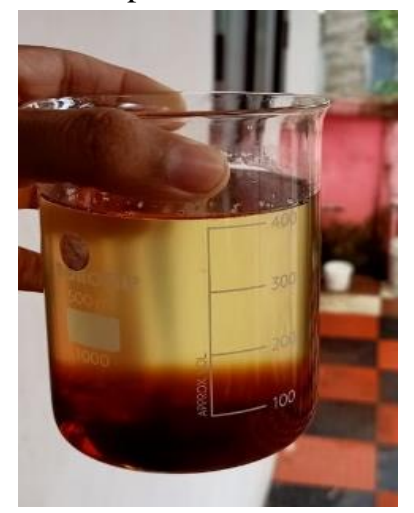

Figure 4 (Separation)

\section{E. Washing}

The top methyl ester layer was separated and removed from the used oil mixture. After we separate the glycerol from the biodiesel is purified by washing gently with warm water to remove remaining residual catalyst or soaps, dried, and sent for storing in a cool and dry place.

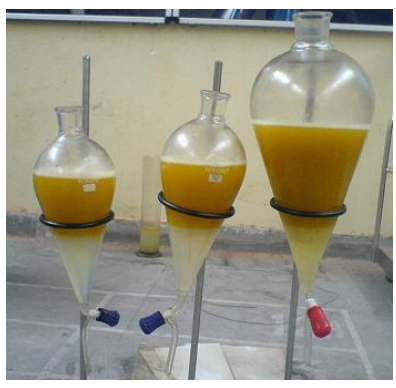

Figure 5 (Washing)

\section{F. Distillation}

We cannot completely remove all of the soaps and catalyst still after washing, therefore, we distil the solution by using a burette apparatus. By gravity and the difference between the density of the different components in our solution the biodiesel parts stay on the top and the glycerin gets settled at the bottom, hence can be easily separated.

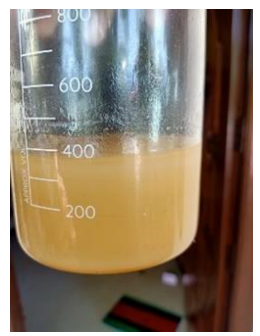

Figure 6 (Distillation)

\section{G. Drying}

During the process of washing the water may be still present in the biodiesel. To remove this water, we take the biodiesel to an oven for drying. Thus we obtain pure biodiesel samples without any impurities or unwanted components.

\section{ANALYSIS}

We have to analysis the properties and performance in the engine. We have 4 types of Bio-Diesel for testing. As we want to compare with a standard fuel we are taking Diesel as the 5 th testing fuel.

We use Normal Diesel -Sample A.

B20 Coconut Oil (80\% diesel, 20\% bio-diesel) -Sample B.

B10 Coconut Oil (90\% diesel, 20\% bio-diesel) Sample C.

B20 Sunflower Oil (80\% diesel, 20\% bio-diesel) Sample D.

B10 Sunflower Oil (90\% bio-diesel,10\%Bio-diesel) Sample E.

The Samples A, B, C, D, E are tested in Diesel Auto rickshaw. As for the convenience, we have used $100 \mathrm{ml}$ of the fuels and tested its mileage. Then we converted into 1 litre. We cannot use these fuels at once if we get better mileage from it. Therefore, we will also be conducting a pollution test to further analyzation. 


\section{A. Mileage test}

From Mileage Test, we can find that the mileage from Sample C (B10 Coconut Oil) is greater than Normal Diesel (Sample A). All other Bio-diesel is having slightly higher mileage than conventional diesel. So from this test, we can understand that Bio-diesel from used cooking is having more mileage. So now we have to conduct an Emission Test.

Table 1 (Mileage)

\begin{tabular}{|l|l|l|l|l|l|}
\hline & $\begin{array}{c}\text { Sample } \\
\text { A }\end{array}$ & $\begin{array}{c}\text { Sample } \\
\text { B }\end{array}$ & $\begin{array}{c}\text { Sample } \\
\text { C }\end{array}$ & $\begin{array}{c}\text { Sample } \\
\text { D }\end{array}$ & $\begin{array}{c}\text { Sample } \\
\text { E }\end{array}$ \\
\hline $\begin{array}{l}\text { Mileage/10 } \\
\text { 0ml }\end{array}$ & 2.4 & 2.7 & 2.9 & 2.5 & 2.6 \\
\hline Mileage/1L & 24 & 27 & 29 & 25 & 26 \\
\hline
\end{tabular}

\section{B. EMISSION TEST}

TABLE 2 (Emission test results)

\begin{tabular}{|l|l|l|l|l|l|}
\hline & $\begin{array}{l}\text { Sample } \\
\text { A }\end{array}$ & $\begin{array}{l}\text { Sample } \\
\text { B }\end{array}$ & $\begin{array}{l}\text { Sample } \\
\text { C }\end{array}$ & $\begin{array}{l}\text { Sample } \\
\text { D }\end{array}$ & $\begin{array}{l}\text { Sample } \\
\text { E }\end{array}$ \\
\hline $\begin{array}{l}\text { Hartridge } \\
\text { Smoke } \\
\begin{array}{l}\text { Units } \\
\text { (\%HSU) }\end{array}\end{array}$ & 28.7 & 34.1 & 30 & 34.4 & 31.8 \\
\hline
\end{tabular}

According to the Norms of ARAI (Automotive Research Association of India, Pune), Diesel engine on BSIV can have a maximum of $50 \% \mathrm{HSU}$. Since we have used an Auto rickshaw with BSIV engine and the HSU\% is less than 35\% but greater than a normal diesel. It has no adverse effect on the environment. So from this Emission Test, we can understand that we can use this fuel in day-to-day usage as the emission is under the limit and has better mileage than conventional diesel. Now we have to analyses the cost of production of Biodiesel.

\section{COST ANALYSIS}

Cost should be the other main factor while using it as an alternative fuel, if the price of the fuel is more than the conventional one with better performance, it cannot be a success in the market. So the analysis of price is given below.

Table 3 (Cost of production)

\begin{tabular}{|l|c|c|c|c|}
\hline & Quantity/100ml & Rate & $\begin{array}{l}\text { Cost } \\
\mathbf{/ 1 0 0 m l}\end{array}$ & Cost $/ \mathbf{L}$ \\
\hline $\begin{array}{l}\text { Used } \\
\text { Oooking }\end{array}$ & $140 \mathrm{ml}$ & 0 & 0 & 0 \\
\hline Methanol & $35 \mathrm{ml}$ & $30 / \mathrm{L}$ & 1.05 & 10.5 \\
\hline $\begin{array}{l}\text { KOH } \\
\text { (Catalyst) }\end{array}$ & $3.5 \mathrm{gr}$ & $50 / \mathrm{kg}$ & .175 & 1.75 \\
\hline Total Cost & & & 1.225 & 12.25 \\
\hline
\end{tabular}

In this experimental setup, we have got around $300 \mathrm{ml}$ of Bio-diesel. So we are trying to calculate the cost it takes for the preparation of $100 \mathrm{ml}$ of Bio-diesel.

The cost of production of Bio-Diesel for 1 litre is ₹12.25/-. So now we have to test the check the price of B10 \& B20 of Sunflower oil and Coconut Oil compared with ordinary
Diesel. As we are creating bio-diesel from UCO through transesterification, we get glycerin as a by-product. We can use glycerin for the production of Soap. It adds revenue to the firm. As this is an experimental setup, we have used waste oil from home, so for the mass production of biodiesel from used cooking oil we can take used oil from the restaurant at an affordable price. So from this, we can understand that when we use Bio-diesel as the fuel it decreases the cost of the fuel, increases mileage, Emission is a bit more but under the limit. The main advantage is that we do not have to replace or modify the engine in order to use this fuel. It can be used an alternative fuel for Diesel. As diesel is not a renewable resource, when we use this type of fuel we can decrease the depletion of fossil fuel.

Table 4 (Cost analysis)

\begin{tabular}{|c|c|c|c|c|c|c|}
\hline & $\begin{array}{c}\text { Sample } \\
\text { A }\end{array}$ & B100 & $\begin{array}{c}\text { Sample } \\
\text { B }\end{array}$ & $\begin{array}{c}\text { Sample } \\
\text { C }\end{array}$ & $\begin{array}{c}\text { Sample } \\
\text { D }\end{array}$ & $\begin{array}{c}\text { Sample } \\
\text { E }\end{array}$ \\
\hline Diesel & 69 & $\begin{array}{ll}- & \text { r }\end{array}$ & $\begin{array}{c}(69 * 0.8 \\
0) \\
=55.2\end{array}$ & $\begin{array}{c}(69 * 0.90 \\
) \\
=62.1\end{array}$ & $\begin{array}{c}(69 * 0.8 \\
0) \\
=55.2\end{array}$ & $\begin{array}{c}(69 * 0.90 \\
) \\
=62.1\end{array}$ \\
\hline $\begin{array}{c}\text { Metha } \\
\text { nol }\end{array}$ & - & $\begin{array}{r}(30 * 0 \\
.350) \\
=10.5 \\
\end{array}$ & $\begin{array}{c}(30 * 0.0 \\
7) \\
=2.1\end{array}$ & $\begin{array}{c}(30 * 0.03 \\
5) \\
=1.05 \\
\end{array}$ & $\begin{array}{c}(30 * 0.0 \\
7) \\
=2.1\end{array}$ & $\begin{array}{l}(30 * 0.03 \\
5)=1.05\end{array}$ \\
\hline $\begin{array}{c}\mathrm{KOH} \\
\text { (Catal } \\
\text { yst) }\end{array}$ & - & $\begin{array}{l}(50 * 0 \\
.035) \\
=1.75\end{array}$ & $\begin{array}{c}(50 * 0.0 \\
07) \\
=0.35\end{array}$ & $\begin{array}{c}(50 * 0.00 \\
35) \\
=0.175\end{array}$ & $\begin{array}{c}(50 * 0.0 \\
07) \\
=0.35\end{array}$ & $\begin{array}{c}(50 * 0.00 \\
35) \\
=0.175\end{array}$ \\
\hline $\begin{array}{c}\text { Total } \\
\text { /L }\end{array}$ & 69 & 12.25 & 57.65 & 63.325 & 57.65 & 63.325 \\
\hline
\end{tabular}

\section{CONCLUSION}

Biodiesel from UCO Has Been Prepared and Tested. The quality of biodiesel was evaluated through a mileage test and emission test which was then compared to ARAI standards. Regarding the production of biodiesel from Used cooking oil (UCO), the following important key points have been highlighted:

a. Several edible oils can be used as UCO feedstock in biodiesel production, such as sunflower oil, palm oil, soybean oil and olive oil etc.

b. Due to its biodegradability, non-toxicity and renewability biodiesel has proven to be one of the best alternatives to diesel fuel.

c. Methanol is being used in the transesterification process because of its low cost and wide availability.

d. Finally the byproduct, glycerol can be used in the preparation of soap which can be made profitable.

From this research, it is clear that Biodiesel is an excellent renewable fuel source. Further research can be carried out in the Biodiesel by varying its composition, changing catalyst, varying reaction time, using dual catalysts to find better performance etc.

\section{REFERENCES}

[1] A Review on Recent Strategy of Biodiesel Production from Waste Cooking Oil and Process Influencing Parameters - A. Gnanaprakasam, V. M. Sivakumar, A. Surendhar, M. Thirumarimurugan, and T. Kannadasan

[2] Overview of the production of biodiesel from Waste cooking oil Zahira Yaakob, Masita Mohammad, Mohammad Alherbawi, Zahangir Alam, Kamaruzaman Sopian.

[3] Production of Biodiesel from used Cooking Oil - S.Gopalakrishnan, J.Ubaidullah, P.Shanmugasundaram, K.Yuvaraj, T.Tamilarasu. 
[4] Biodiesel production from waste cooking oil - Maria Sarno and Mariagrazia Luliano

[5] Biodiesel Production Based on Waste Cooking Oil (WCO) - Nor Hazwani Abdullah, Sulaiman Haji Hasan, and Nurrul Rahmah Mohd Yusoff

[6] Biodiesel production from waste cooking oil- Mohammed Abdul Raqeeb and Bhargavi R.

[7] Preparation of biodiesel from waste cooking oil via two-step catalyzed process - Yong Wang, Shiyi Ou, Pengzhan Liu, Zhisen Zhang

[8] Synthesis of biodiesel from second-used cooking oil -Wanodya Asri Kawentar and Arief Budiman 